\title{
The Region of Matching of Central-Asian Mobile Belt and Pacific Mobile Belt
}

\author{
Inna Derbeko \\ Far Eastern Russian Academy of Sciences, Institute of Geology and Nature Management, Blagoveschensk, Russia \\ Email: derbeko@mail.ru
}

Received February 15, 2013; revised March 17, 2013; accepted April 18, 2013

Copyright (c) 2013 Inna Derbeko. This is an open access article distributed under the Creative Commons Attribution License, which permits unrestricted use, distribution, and reproduction in any medium, provided the original work is properly cited.

\begin{abstract}
Central Asian and Pacific mobile belts are the two geological superstructures of Eastern Asia. They keep many geological secrets. There is a region of the interaction of the structures in the frames of the margin of East Asia. The region is ambiguous. It is denominated in tectonic superposition or covering (interference) of the segments of the structures. The main goal of the research work is to establish the boundary line of the jointing of two superstructures. Here we show the role of the Mesozoic tectonic restructuring and magmatism in the interaction of the structures. The region of their jointing is the boundary line between Bureja-Jziamusy and Badzhal terrains. The boundary line in the frames of Mongol-Okhotsk orogenic belt is disputable. Geochronological and paleomagnetic data and chemical composition of the volcano-plutonic rocks of the eastern margin of Mongol-Okhotsk belt and of the structures of Central-Asian mobile belt were recently obtained. The data allow us to review the region of the joint of the two structures of eastern Asia. It was suggested to draw the boundary line of the joint (in this case-interference) of Central Asian mobile belt and Pacific mobile belt in the frames of the eastern margin of Mongol-Okhotsk orogenic belt along the margin of the disappearance of late Mesozoic oversubductional volcano-plutonic complexes in the western direction. The structure of Bureja-Jziamusy superterrain was related to the structures of the Pacific mobile belt. The proposed model of the region of jointing of two East Asian superstructures enables us to reconsider the tectonic and geodynamical and metallogeny schemes of evolution of the Eastern margin of Asia.
\end{abstract}

Keywords: Mobile Belt; Mesozoic; Volcano-Plutonic Complex; Mongol-Okhotsk Orogenic Belt

\section{Introduction}

Region of the matching of Central-Asian and Pacific mobile belts (Figure 1) is stated in the zone of the joint of the Eastern margin of Bureja-Jziamusy superterrain and the western margin of Badzhal terrain [1-4].

The boundary line in the frames of the Mongol-Okhotsk orogenic belt is variable. Various authors state the boundary line differently [2-4]. Mongol-Okhotsk orogenic belt takes the axial position in the structures of the Central Asia and [5] is stretching in sublatitudinal direction for more than 2.5 thousand $\mathrm{km}$ from gulf of Uda of Okhotsk Sea on the East to Central Mongolia on the West, where the belt blows out as obtuse angle (Figure 2(a)). Mongol-Okhotsk orogenic belt is separated from North-Asian craton and its framing by the zone of NorthTukuringra fault line. It adjoins Argun and Bureja-Jziamusy superterrain on the south and South-Mongolian, Sikhote-Alin-North-Sakhalin orogenic belts and Badzhal terrain (Figure 2(a)). These structures are the northern frames of Chino-Korean craton [6]. In the upper reaches of Amur river the ancient continental blocks joint each other and absorbed about $200 \mathrm{~km}$ of the belt, dividing it in two units: western and eastern (Figure 2(a)).

\section{Structures of Mongol-Okhotsk Orogenic Belt}

In the structure of the eastern unit of the belt the terrains of the accretion wedge are separated. Turbidites prevail in the composition of Lansk, Unia-Bomsk and Ulbansk terrains. Oceanic formations prevail in Tukuringra-Dzhagda and Nilan terrains [5] (Figure 2b).

Lansk terrain is presented with the lower-middle Devonian turbidites with the stratums of jasper, basalts, tuffs, diabases and chalkstones. There are zones of mélange where blocks of the sandstones, aleurolites, limestones with Silurian corals and early Cambrian archaeocyathas are rolled up in aleuro-argillitic matrix. Lower and upper Triassic sediments are presented with turbid- 


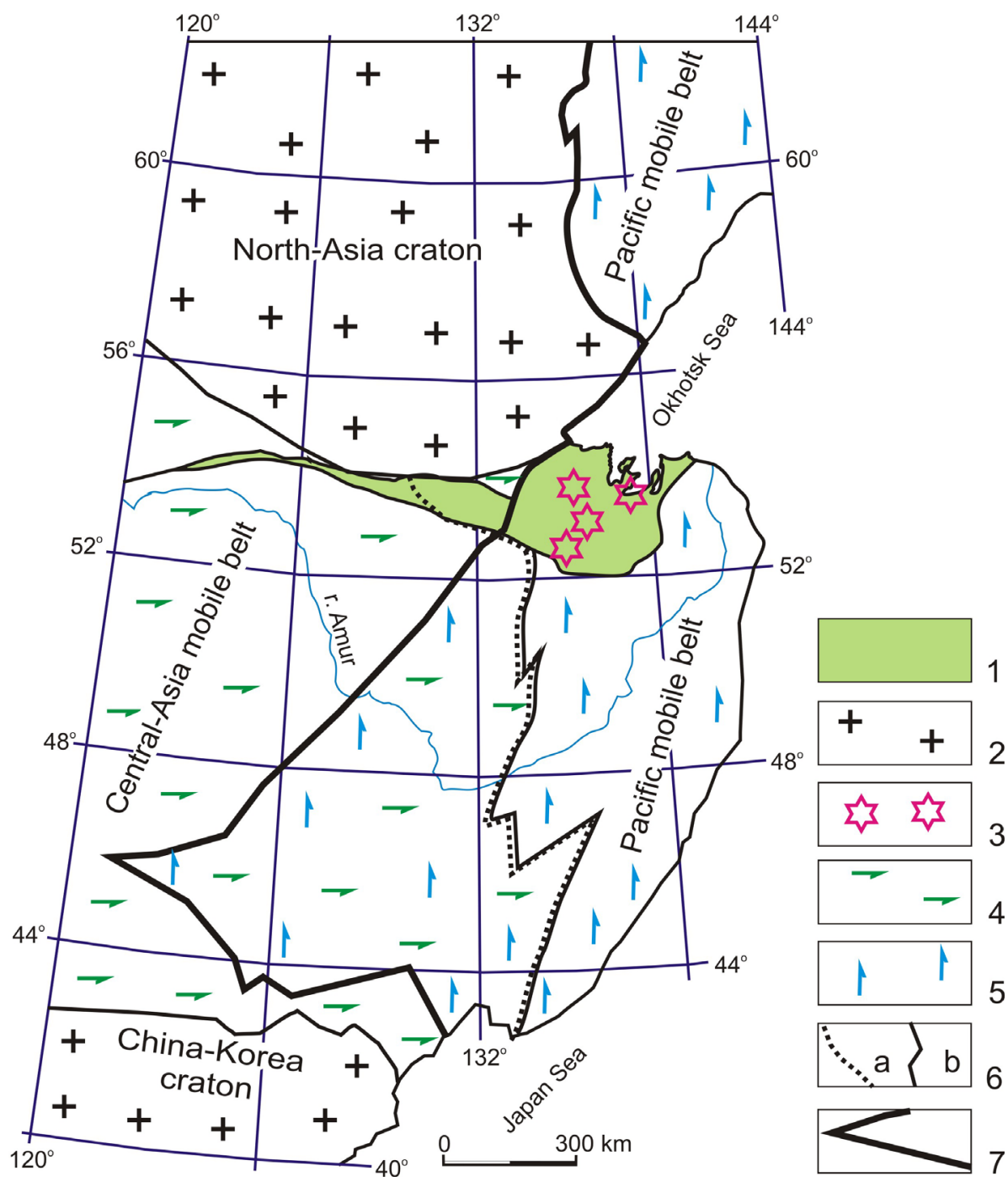

Figure 1. Scheme of the matching of the Central-Asian mobile belt and Pacific mobile belt. 1) Mongol-Okhotsk orogenic belt; 2) Precambrian cratones; 3) Early Cretaceous volcano-plutonic zones; 4) Central-Asian mobile belt; 5) Pacific mobile belt; 6) The border of the jointing of Central-Asian mobile belt and Pacific mobile belt: (a) by the data of 4; (b) By the data of 1 - 3; 7) By the data of the author.

ites with boreal fossil fauna. Shallow-sea sediments of upper and middle Jurassic finish the rock sequence [6].

Unia-Bomsk terrain is presented with late Triassicearly Jurassic turbidites where the flysch deposits, basalts, deepwater silicic and argillic-silicic rocks, shallow-water conglomerates and sandstones with the floral detritus are present. Marbled limestones with oncolites and catagraphites, that are characteristic for the rocks of North Asian craton and limestones containing late Permian moss animals are occurred among the zones of mélange [7].

Galam terrain is formed with associations of the rocks of Silurian, Devonian and early Carboniferous age. The rocks are as follows-jasper, ribbon silicium, silicic-argillaceous slates, basalts; terrigenic stratified formations with the signs of the turbidite sedimentation; olistostromes with the inclusions of the low Cambrian limestones, si- licic limestones, flints and diabases [6].

Ulban terrain it is formed with upper Triassic-lowermiddle Jurassic turbidites, that are tectonically mixed with small values of the flints, containing middle Jurassic radialaries and metabasalts [6].

Tukuringra-Dzhagda terrain is formed with the tectonic lenses or blocks of the limestones of late Proterozoic with oncolites and catagraphites; Silurian and Devonian basalts, silicic, silicic-argillaceous rocks with limestone lenses, containing corals and crinoids, and terrigenic rocks with Givetian brachiopods of Central Asian type; late Cambrian and early Permian flysch, green slates with tetical corals and fuzulinides; tectonic lenses of ophiolites that consist of gabbro, amphibolites, pyroxenites, serpentinites and plagiogranites [7].

Nilan terrain is represented with lower and middle 


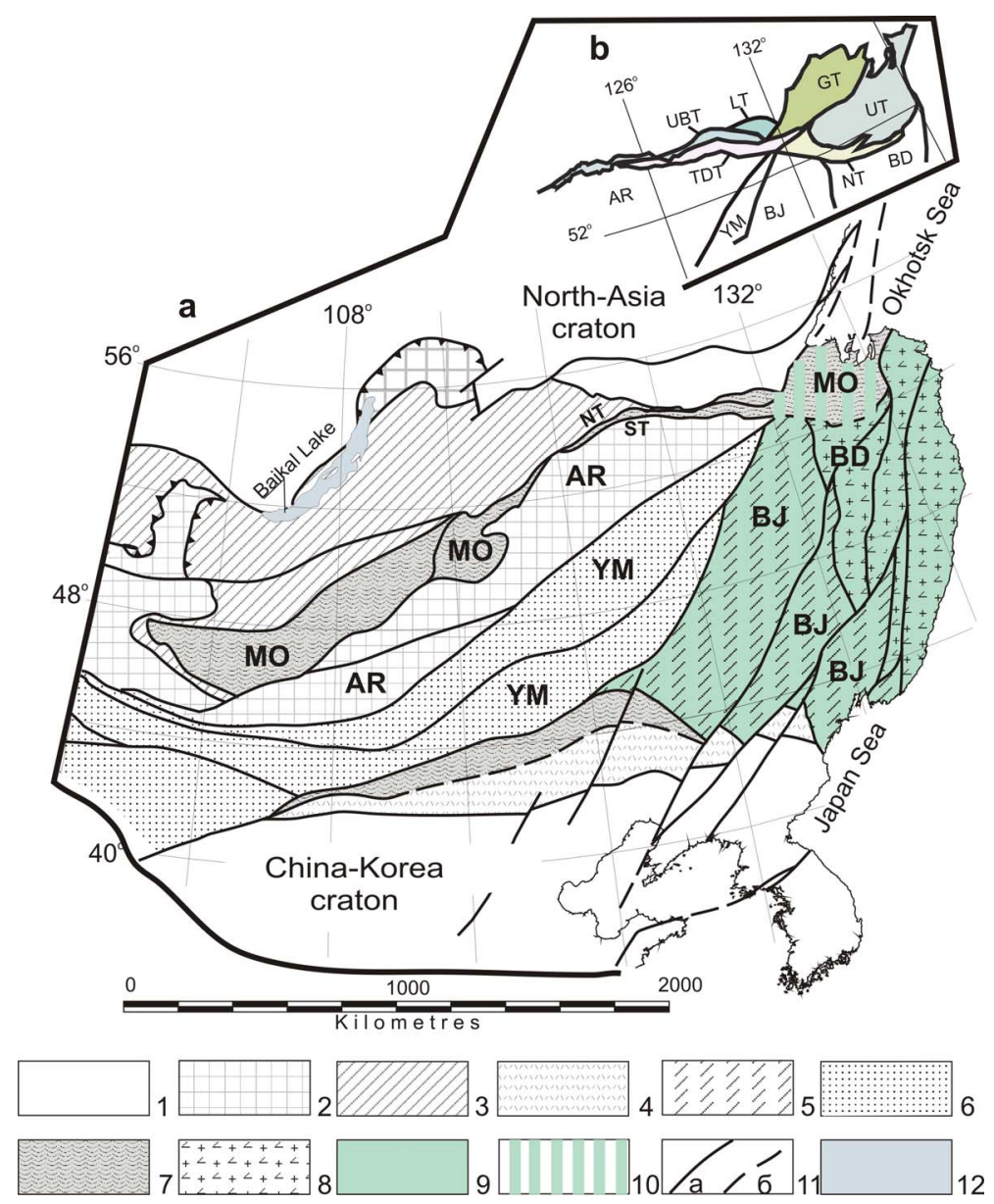

Figure 2. Scheme of the Central-Asia and Pacific mobile belts. The scheme is dew [5]. (a) Craton-1: North Asian, Chino-Korean. Orogenic belts and the fragments of orogenic belts: Late Rhyphean-2, Late Cambrian-Early Ordovician-3, Silurian-4, Early Paleozoic-5, Late Paleozoic-6, Late Paleozic-Early Cretaceous-7, Late Jurassic-Early Cretaceous-8. Structures, related to Pacific belt-9. Region of the interferences of the mobile belts-10. Tectonic contacts-11: (a) determined, (b) assumed. Water basins-12. Letter symbols: (a) and (b) BJ: Bureja-Jziamusy and A: Argun Superterrains; BD: Badzhal terrain; MO: Mongol-Okhotsk orogenic belt, YM: South-Mongolian-Khingansk orogenic belt; NT: North Tukuringra and ST: South Tukuringra tectonic contacts. (b) Terrains: UBT: Unia-Bomsk, LT: Lansk, GT: Galam, UT: Ulban, TDT: Tukuringra-Dzhagda, NT: Nilan.

Devonian sediments, containing the remains of corals, brachiopodes and crinoids, typical for the Central Asian structures; Lower Carboniferous formations characterized with foraminifers, corals, moss animals and brachiopodas that are also occurred in other terrains of Mongol-Okhotsk belt. The mélange zone is formed with the argillaceous matrix with Jurassic radiolaries with the boulders of low Carboniferous limestones. Upper Carboniferous flysch of the terrain contains the remains of crinoids and Angara flora. Permian deposits of the continental descents complete the outcrop [6].

\section{Late Mesozoic Volcano-Plutonic Formations}

It is considered that [6], the continental volcanites and combined granite plutones of late Neocomiumlate Cre- taseous overcover and "saw" the terrains of the eastern unit of Mongol-Okhotsk orogenic belt. Against the supposition speaks the spatial dislocation of the late Mesozoic volcano-plutonic complexes. At the length of the eastern union of the belt at about $1000 \mathrm{~km}$ this complexes are dislocated exclusively at its eastern margin and are observed not longer than $250 \mathrm{~km}$ from the border of the continent. Dew to the last precision material composition [8-11] late Mesozoic volcano-plutonic formations of the eastern unit of Mongol-Okhotsk orogenic belt is the oversubductional formations.

Late Mesozoic volcano-plutonic formations of the eastern unit of Mongol-Okhotsk orogenic belt are presented by two volcano-plutonic complexes: Selitkan and EzopJamalin. The made research work [8-11] proves that the dislocation of the microelements in the data of the volcano-plutonic formations correlates with the scheme of 
their dislocation in the rocks of the subductional situations: enrichment with the large ion elements (K, Cs, Rb, $\mathrm{Ba}, \mathrm{Pb})$, LREE, combination with high-charged elements - (Nb, Ta, Zr, Hf) and HREE. Sr and Ti make an exception. They show heightened concentrations in the rocks of main-medium composition. Presence of the elements becomes lower in the rocks of the acid composition. Lowering of $\mathrm{Sr}$ in the rocks shows the attenuation of the subduction processes in the region. Diagram of the correlation of $\mathrm{Sc} / \mathrm{Ni}-\mathrm{La} / \mathrm{Yb}$ (Figure 3) illustrates the comparability of the composition of the rocks of Late Mesozoic volcano-plutonic formations of the eastern unit of Mongol-Okhotsk orogenic belt with the volcanites of Andian continental margin.

Period of their formations points at relatively short geological developments, almost catastrophic ones. They occurred at the continental margin in interval of 105 $100 \mathrm{Ma}$ (Selitkan volcano-plutonic complex) and 95 - 90 Ma (Ezop-Jamalin volcano-plutonic complex) [9,11]. According to their relations with the containing rocks they trace the zone of overthrust of Ulban terrain on the Paleozoic formations of Nilan terrain. Probably the formation of the volcano-plutonic complexes is syngenetic to the tectonic developments of the period.

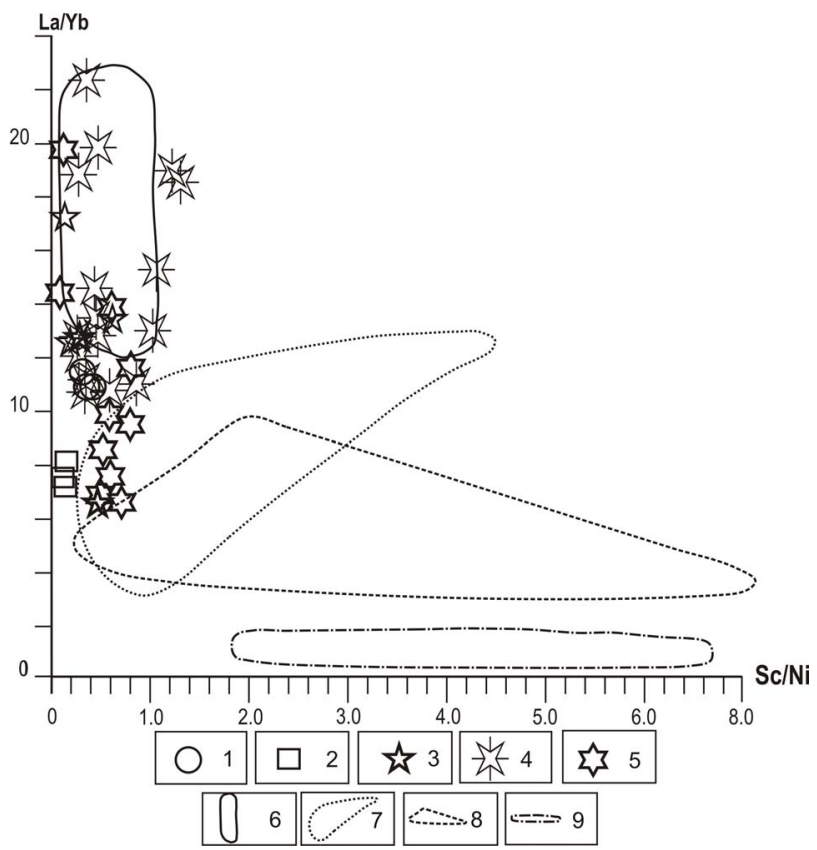

Figure 3. Ratio of the microelements $\mathrm{La} / \mathrm{Yb}-\mathrm{Sc} / \mathrm{Ni}$ in the volcano-plutonic complexes. Volcano-plutonic complexes of the Bureja-Jziamusy superterrain (1 - 3): 1) Pojarka; 2) Burunda; 3: Stanolir. Volcano-plutonic complexes of the Eastern margin of Mongol-Okhotsk orogenic belt (4 - 5): 4) Selitkan; 5) Ezop-Jamalin. Fields of the rocks by the data of [12] (6 - 9): 6) Andian active continental margin; 7) island arcs, laying on the continental crust; 8) island arcs, laying on the oceanic crust; 9) low-potassic oceanic basaltes.
The structure of the western union is reflected in the model of the following authors [13-18]. According to the suggested model, evolution of Mongol-Okhotsk orogenic belt in Phanerozoic was due to North Asian and ChinoKorean cratons collision. The collision processes in this region were combined with wide magmatic intraplate processes. They were accompanied by the affection of plume at the area that is under the conditions of the collision compression. At the beginning of the early Cretaceous (190 Ma) this processes finished with the closure of the western part of Mongol-Okhotsk basin [18].

Due to the authors, the affection of the plume moved in the eastern direction. Rejuvenation of magmatism occurred in the same direction. This development finished in 119 - 97 Ma with the complete closure of MongolOkhotsk basin [19]. The researched developments were accompanied by the formation of the intraplate bimodal complexes along all the framing of Mongol-Okhotsk belt. Practically, their age fixed the stages of the closure of two cratons. In the southern framing of Mongol-Okhotsk orogenic belt the development of the bimodal complexes is limited by the structures of Bureja-Jziamusy superterrain. On the territory of Bureja-Jziamusy superterrain the age interval (120 - $105 \mathrm{Ma}$ ) is marked by the volcanic activity, due to the subduction processes [20]. The rocks of the calk-alkali volcanic complexes with typically subductional petrochemical and geochemical characters: high content of $\mathrm{Sr}$ and low content of $\mathrm{Nb}, \mathrm{Ta}, \mathrm{Rb}, \mathrm{K}$, Ti were formed.

They are also dislocated in the field of the active continental margins of Andian type as it is shown on Figure 3. With all that, all the types of Burunda complex rocks are situated in the field of the rocks that were formed under conditions of island arc laying on the continental crust [21].

\section{Paleomagnetic Data}

The paleomagnetic data were obtained by U. Bretstein and A. Klimov [6] for the main tectonic elements of the south of Russian Far East (Figure 4). According to the data Bureja-Jziamusy superterrain occurred at a significant length from North Chinese plate in Jurassic. This fact is also confirmed by the paleomagnetic research work of S. Pisarevsky [22]. Magmatic processes completely extinguish during 105 - $101 \mathrm{Ma}$ on the territory of Bureja-Jziamusy superterrain. The situation of the continental riftogenesis begins to appear $101 \mathrm{Ma}$ [19]. That affected the formation of the intraplate volcano-plutonic complex of acid-alkali rocks. The author considers the collision of Bureja-Jziamusy superterrain and Badzhal terrains as the most probable tectonic scenario of the formation of the volcano-plutonic complex. This is also confirmed by the paleomagnetic data (Figure 4). It fol- 


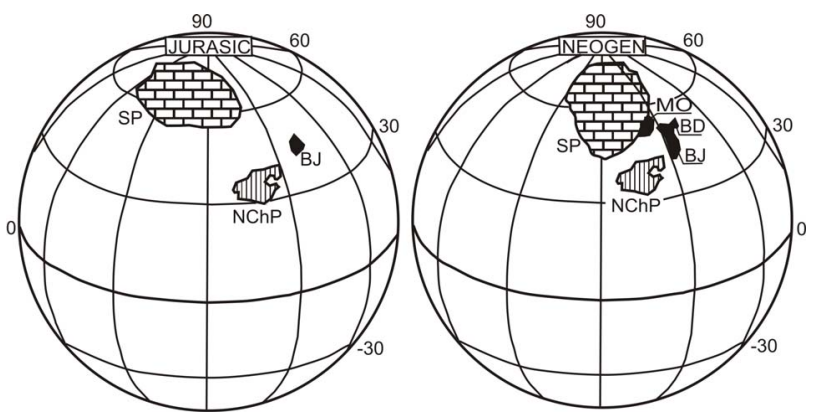

Figure 4. Palinspatic reconstruction of the location of the main tectonic units of the south of the Far East of Russia in Jurassic-Neogene [6]. Letter symbols: SP: Siberian plate; NChP: North-Chinese plate; BJ: Bureja-Jziamusy superterrain (by U. Bretstein and A. Klimov [6]—Khingan-Bureya plate); BD: Badzhal terrain; MO: Mongol-Okhotsk orogenic belt.

lows that Bureja-Jziamusy superterrain was not a part of the Central Asian folded belt till Jurassic. It took part in tectonic rebuildings associated with evolution of Pacific basin.

\section{Conclusion}

Eastern unit of Mongol-Okhotsk orogenic belt is represented by the collage of terrains of the accretion wedge. Age and substantial composition of some of the terrains indicates the genetic connection with the formations of the Central Asian mobile belt. In the northern and southern framing of the eastern Mongol-Okhotsk orogenic belt (except Bureja-Jziamusy superterrain) in the interval 140 120 Ma the oversubductional volcano-plutonic complexes were formed [20]. Only after 120 Ma they were changed into sin- and postcollisional formations, which forming ended by the beginning of the late Cretaceous. Two short-time magmatic impulses were noted on the margin of the eastern unit of the orogenic belt (105 - 101 $\mathrm{Ma}$ and 95 - $90 \mathrm{Ma}$ ) that formed oversubductional volcano-plutonic complexes. The complexes accompanied the lowering of the oceanic plate under the continental margin of Mongol-Okhotsk belt. The time of the formation of the oversubductional formations correlate with the period of time when the closure of Mongol-Okhotsk basin was close to its conclusion: Ulban Jurassic terrain obducts the Paleozoic formations of Nilan terrain. These tectonic events, associated with the evolution of the $\mathrm{Pa}-$ cific mobile belt, had a pulsating character and were accompanied by magmatic activity: 105 - $101 \mathrm{Ma}$ and 95 90 Ma. Bureja-Jziamusy superterrain during this time interval was at a considerable distance from the forming continent [6]. The conjunction of the continent and the superterrain occurred much later than in Jurassic period dew to the paleomagnetic data [6]. It is suggested to draw a boundary line of the joint (interference in this case) of the Central Asian mobile belt and Pacific mobile belt along the boundary line of the disappearance of the late Mesozoic oversubductional volcano-plutonic complexes in western direction on the eastern margin of Mongol-Okhotsk orogenic belt. It is based on the considered scheme of the geological development of the region. The structure of Bureja-Jziamusy superterrain can be related to the structures of the Pacific mobile belt (Figure 1).

\section{REFERENCES}

[1] L. M. Parfenov, N. A. Berezin, A.I. Khanchuk, G. Badarh, V. G. Belichenko, A. N. Bulgatov, S. I. Drill, G. L. Kirillova, M. I. Kuzmin, U. Nokleberg, A. V. Prokopiev, V. F. Timofeev, O. Tomurtogoo and H. Yan, "The Model of the Formation of the Orogenic Belts of Central and Northern-Eastern Asia,” Russian Journal of Pacific Geology, Vol. 22, No. 6, 2003, pp. 7-41.

[2] G. A. Shatkov and A. S. Volsky, “Tectonics, Deep Structure and Minerageny of the Amur Region and Adjacent Areas,” VSEGEI Press, St.-Petersburg, 2004.

[3] G. A. Shatkov and A. S. Volsky, “Tectonics, Deep Structure and Metalogeny of the Region of Joining of Central Asian and Paciffic Belts,” FEB RAS Press, Vladivostok, 2005.

[4] Y. F. Malyshev, V. Y. Podgorny, B. F. Shevchenko, N. P. Romanovsky, V. B. Kaplun and P. Y. Gornov, "Deep Structure of the Bounding Zone Structures of the Amur Lithospheric Plate,” Russian Journal of Pacific Geology, Vol. 26, No. 2, 2007, pp. 3-17.

[5] L. M. Parfenov, L. I. Popeko and O. Tomurtogoo, "The Problems of Tectonics of Mongol-Okhotsk Orogenic Belt," Russian Journal of Pacific Geology, Vol. 18, No. 5, 1999, pp. 24-43.

[6] A. I. Khanchuk, "Geodynamics, Magmatism and Metallogeny of the Russian East,” Dalnauka Press, Vladivostok, 2006.

[7] G. L. Kirillova and M. T. Turbin, "Formations and Tectonics of Dzhagdinsk Unit of Mongol-Okhotsk Forlded Region,” Nauka, Moscow, 1979.

[8] I. M. Derbeko, "Scheme of the Formation of Magmatic Complexes of the Selitkan Volcano-Plutonic Zone, the Eastern Flank of the Mongol-Okhotsk Orogenic Belt (Russia)," Geochemistry International, Vol. 47, No. 11, 2009, pp. 1083-1099. doi:10.1134/S0016702909110044

[9] I. M. Derbeko, A. A. Sorokin, V. A. Ponomarchuk, A. V. Travin and A. P. Sorokin, "First Geochronological Data on Felsic Lavas from the Ezop-Yamalin Volcanoplutonic Zone, Khingan-Okhotsk Volcanogenic Belt," Doklady Earth Sciences, Vol. 419, No. 2, 2008, pp. 231-234. doi:10.1134/S1028334X08020098

[10] I. M. Derbeko, A. A. Sorokin, E. B. Sal'nikova, A. B. Kotov, A. P. Sorokin, S. Z. Yakovleva, A. M. Fedoseenko and Y. V. Plotkina, "Age of Felsic Volcanism in the Selitkan Zone of the Khingan-Okhotsk Volcanoplutonic Belt, Russian Far East,” Doklady Earth Sciences, Vol. 418, No. 1, 2008, pp. 28-31. doi:10.1134/S1028334X08010078 
[11] I. M. Derbeko, A. A. Sorokin and S. G. Agafonenko, “Geochemical Features of Felsic Magmatism on the NorthWestern Flank of the Khingan-Okhotsk Volcanoplutonic Belt: Ezop and Yam-Alin Zones," Russian Journal of Pacific Geology, Vol. 27, No. 2, 2008, pp. 54-63.

[12] H. R. Rollinson, "Using Geohemical Data: Evalution, Presentation, Interpretat,” 1995.

[13] V. V. Yarmolyuk, V. G. Ivanov, I. V. Kovalenko and B. G. Pokrovsky, "Magmatism and Geodynamics of the Southern Baikal Volcanic Region (Mantle Hot Spot): Results of Geochronological, Geochemical, and Isotopic ( $\mathrm{Sr}, \mathrm{Nd}$, and $\mathrm{O}$ ) Investigations. Petrology, Vol. 11, No. 1, 2003, pp. 3-34.

[14] V. V. Yarmoluk and V. I. Kovalenko, "Geochemical and Isotope Parameters of Abnormal Mantel of North Asia in Late Mesozoic (by Data of the Examination of Intraplatal Basalt Magmatism)," Doklady Earth Sciences, Vol. 375, No. 4, 2000, pp. 525-530.

[15] V. V. Yarmoluk, V. I. Kovalenko and M. I. Kuzmin, "NorthAsia Activity Superplume in the Phanerozoic: Magmatism and Geodynamics," Geotectonics, No. 5, 2000, pp. 3-29.

[16] V. V. Yarmoluk, V. I. Kovalenko, E. B. Salnikova, S. V. Budnikov, V. P. Kovach, A. B. Kotov and V. A. Ponomarchuk, "Tectono-Magmatic Zoning, Magma Sources and Geodynamics of the Early Mesozoic Mongol-Transbaikal Province," Geotectonics, No. 4, 2002, pp. 42-63.

[17] V. I. Kovalenko, V. V. Yarmoluk and E. B. Salnikova,
"Sources of the Magmatic Rocks and Formation of Early Mesozoic Tecktono-Magmatic Areal of Mongol-Transbaikalian Magmatic Area: Geological Characteristic and Isotope Geochronology,” Petrology, Vol. 11, No. 2, 2003, pp. 164-178.

[18] O. A. Bogatikov and V. I. Kovalenko, "Types of Magma and Their Sources in the History of the Earth,” IGOD RAS Press, Moscow, 2006.

[19] I. M. Derbeko, "Bimodal Volcano-Plutonic Complexes in the Frames of Eastern Member of Mongol-Okhotsk Orogenic Belt, as a Proof of the Time of Final Closure of Mongol-Okhotsk Basin,” In: F. Stoppa, Ed., Updates in Volcanology-A Comprehensive Approach to Volcanological Problems, InTech, Rijeka, 2012, pp. 99-124.

[20] I. M. Derbeko, "Late Mesozoic Volcanism of MongolOkhotsk Belt (Eastern End and the Southern Framing of Eastern Member of the Belt),” LFMBERT Academic Publishing GmbH\&Co. KG, Saarbruken, 2012, pp. 59-97.

[21] I. M. Derbeko, S. G. Agafonenko, S. K. Kozyrev and D. L. Vyunov, "The Umlekan-Ogodzha Volcanic Belt (the Problem Bodily Separation)," Lithosphere, No. 3, 2010, pp. 70-77.

[22] S. A. Pisarevsky, "New Edition of the Global Paleomagnetic Database," EOS Transactions American Geophysical Union, Vol. 86, No. 17, 2005, p. 170. doi:10.1029/2005EO170004 